\title{
Peran Orientasi Kewirausahaan Sebagai Mediasi Antara Pendidikan dan Minat Berwirausaha Pada Mahasiswa
}

\author{
Abrista Devi \\ Universitas Ibn Khaldun, Bogor, Indonesia \\ Email: abristasmart@gmail.com
}

\begin{abstract}
Nowadays, university is focused on how to prepare their graduated student to be an employee, but forgetting on how to prepare them to be an entrepreneur. There are some obstacles why university students have lack of an intention to do business, starting with lack of capital, lack of skill, have no confidence, selective in choosing job, and some other factors. These problems is strengthtened by the data found that Indonesia is highly need more entrepreneurs, where the numbers of entrepreneurs is still less than 2\% from total GDP (Gross Domestic Product of a country). This study is aimed to identify the effect of entrepreneurial education to entrepreneurial orientation of university student, the effect of entrepreneurial orientation to entrepreneurial intention, and the direct and indirect effect of entrepreneurial education to entrepreneurial intention. This study takes Ibn Khaldun University, Islamic Economics major students as case study of respondents. This study employs quantitative approach with SEM (Structural Equation Modeling) methodology. The findings of this study are, entrepreneurial education has positive and significant effect to entrepreneurial orientation; entrepreneurial orientation has positive and significant effect to entrepreneurial intention; and entrepreneurial education has positive and significant effect to entrepreneurial intention indirectly through entrepreneurial orientation.
\end{abstract}

Keywords: Entrepreneurial Education, Entrepreneurial Orientation, Entrepreneurial Intention, Structural Equation Modeling.

\begin{abstract}
Abstrak
Saat ini, universitas difokuskan pada bagaimana mempersiapkan siswa lulusan mereka untuk menjadi pegawai, namun lupa bagaimana mempersiapkan mereka untuk menjadi pengusaha. Ada beberapa kendala mengapa mahasiswa tidak memiliki niat untuk berbisnis, dimulai dengan kekurangan modal, kurang keterampilan, tidak percaya diri, selektif dalam memilih pekerjaan, dan beberapa faktor lainnya. Masalah ini diperkuat oleh data yang ditemukan bahwa Indonesia sangat membutuhkan lebih banyak wirausahawan, dimana jumlah wirausahawan masih kurang dari 2\% dari total PDB (Produk Domestik Bruto suatu negara). Penelitian ini bertujuan untuk mengetahui pengaruh pendidikan kewirausahaan terhadap orientasi kewirausahaan mahasiswa, pengaruh orientasi kewirausahaan terhadap wirausaha, dan pengaruh langsung dan tidak langsung pendidikan kewirausahaan terhadap wirausaha. Studi ini mengambil Universitas Ibn Khaldun, mahasiswa jurusan Ekonomi Islam sebagai studi kasus responden. Penelitian ini menggunakan pendekatan kuantitatif dengan metodologi SEM (Structural Equation Modeling). Temuan penelitian ini adalah, pendidikan kewirausahaan memiliki pengaruh positif dan signifikan terhadap orientasi
\end{abstract}


kewirausahaan; Orientasi kewirausahaan memiliki pengaruh positif dan signifikan terhadap wirausaha; dan pendidikan kewirausahaan berpengaruh positif dan signifikan terhadap niat kewirausahaan secara tidak langsung melalui orientasi kewirausahaan.

Kata Kunci: Wirausaha Pendidikan, Orientasi Wirausaha, Niat Wirausaha, Pemodelan Persamaan Struktural.

\section{A. Pendahuluan}

Berdasarkan data yang dilansir oleh BPS (Badan Pusat Statistik) mengungkapkan bahwa bulan Februari tahun 2013 ada sekitar 7 juta penganggur di Indonesia, 421.717 orang diantaranya adalah lulusan universitas, dan 192.762 orang merupakan lulusan diploma. Penyebab dari pengangguran sarjana sebagaimana diungkap oleh Fashoyin dan Tiraboschi (2012) diantaranya adalah (i) lulusan perguruan tinggi yang dihasilkan kurang kompeten, (ii) minimnya network, (iii) program-program yang diberikan di bangku kuliah kurang efektif untuk masa transisi dari bangku kuliah ke dunia kerja, (iv) sikap selektif mahasiswa yang berlebihan, (v) banyaknya kuantitas lulusan yang dihasilkan setiap tahun, dan (vi) minimnya lapangan kerja. Minimnya lapangan pekerjaan tentunya menjadi perhatian serius tidak hanya bagi pemerintah maupun instansi-instansi terkait seperti lembaga keuangan profit maupun non-profit yang bertanggungjawab akan tersedianya lapangan pekerjaan, akan tetapi universitas sebagai lembaga pendidikan yang mendidik serta membina generasi bangsa juga turut berperan penting dalam menjamin ketersediannya lapangan pekerjaan di Indonesia.

Saat ini kebanyakan universitas di Indonesia hanya focus pada bagaimana menghasilkan lulusan yang siap dipakai di dunia kerja. Kurikulum-kurikulum pendidikan, kegiatan kemahasiswaan hingga praktik pembelajaran semuanya disiapkan guna memenuhi kebutuhan industri yang diharapkan dapat menyerap lulusan perguruan tinggi. Padahal aspek terpenting dari wujudnya kampus sebagai wadah pembentuk karakter dan keahlian mahasiswa adalah dengan menciptakan para lulusannya tidak hanya mampu bersaing di dunia kerja, akan tetapi juga mampu menciptakan lapangan pekerjaan. Jika demikian, maka minimnya lapangan pekerjaan bukan lagi menjadi masalah, angka tingkat pengangguran dapat diminimalisir, ekonomi kerakyatan pun dapat ditingkatkan dengan bertambahnya jumlah wirausaha dan UMKM. Tidak hanya masalah yang ada di universitas itu sendiri, permasalahan lainnya juga berasal dari mahasiswanya. Beberapa hasil penelitian yang dilakukan oleh (Amrullah, 2012; Fitriati, 2012; Rahmawati, dkk, 2010) mengungkapkan bahwa kebanyakan dari lulusan perguruan tinggi baik jurusan bisnis maupun non bisnis, mereka tidak memiliki minat untuk menjadi entrepreneur. Terhitung hanya 17\% lulusan perguruan tinggi yang memiliki komitmen untuk menjadi entrepreneur. Menurut Iskandarini (2011) terdapat beberapa faktor yang menyebabkan kurangnya minat 
berwirausaha seperti tidak ada modal, tidak ada keahlian, dan tidak percaya diri.

Dalam rangka mewujudkan negara berkembang, suatu negara harus memiliki sekurang-kurangnya $2 \%$ wirausaha dari jumlah populasi penduduknya (McCelland dalam Rochmah, 2013). McCelland juga menyatakan bahwa prosentase jumlah wirausaha di Malaysia saat ini tercatat sekitar 4\% dari total penduduknya dan Singapura sekitar $7,2 \%$, Amerika dan China terhitung memiliki $11,5 \%$ dan $10 \%$. Sedangkan Indonesia, yang memiliki populasi penduduk terbesar setelah China hanya memiliki wirausaha tidak lebih dari $2 \%$. Masalah ini tentunya patut diberi perhatian lebih baik oleh pemerintah maupun lembaga-lembaga terkait lainnya mengingat kewirausahaan merupakan aspek penting yang dapat menyelamatkan perekonomian negara, menyumbang angka terbesar dalam mewujudkan kesejahteraan rakyat, meningkatkan GDP dan pendapatan perkapita masyarakat dan terpenting lagi adalah mampu mengatasi masalah-masalah sosial yang pada setiap tahunnya menjadi masalah tak berujung di negeri ini seperti misalnya kemiskinan, pengangguran, kriminalitas dan sebagainya. Universitas merupakan "seats of learning" (Helyer, 2011). Komunitas kampus berperan penting dalam pembangunan ekonomi secara regional (Mars dan Ginter, 2012). Namun sayangnya, peranan ini (baik dari manajemen kampus, mahasiswa dan staf kampus) terlihat belumlah optimal untuk menciptakan setiap individu kampus menjadi seorang entrepreneur muda (Mars dan Ginter, 2012). Berkaca pada kesuksesan negara maju seperti amerika dan eropa yang hampir seluruh perguruan tingginya menyisipkan materi entrepreneurship dihampir setiap mata kuliahnya, negara-negara di asia seperti jepang, singapura dan malaysia juga menerapkan materi-materi entrepreneurship minimal di dua semester (Pittaway dan Cope, 2007).

Di Indonesia, usaha-usaha untuk menanamkan jiwa dan semangat kewirausahaan diperguruan tinggi terus digalakan dan ditingkatkan. Hal ini dapat terlihat dengan semakin banyaknya universitas baik yang memiliki jurusan kewirausahaan maupun tidak memiliki jurusan kewiruasahaan telah menerapkan mata kuliah kewirausahaan menjadi salah satu mata kuliah dasar bagi semua jurusan. Tidak hanya itu, program-program kewirausahaan juga terus dikembangkan guna mendukung berkembangnya kemampuan kewirausahaan seseorang (Fayolle, 2007). Seperti misalnya di Universitas Indonesia dimana UI menerapkan model pendidikan kewirausahaan melalui lima cara, yaitu melalui: (i) kurikulum pendidikan; (2) unit incubator bisnis; (3) center for entrepreneurship development and studies sebagai unit kegiatan mahasiswa; (4) lomba olimpiade ilmiah mahasiswa yang diadakan oleh Badan Eksekutif Mahasiswa Universitas Indonesia, dimana salah satu jenis lomba yaitu penulisan program kreatifitas mahasiswa kewirausahaan; (5) membangun keterampilan dan karakteristik kewirausahaan dengan mengintegrasikan pada mata kuliah atau 
kegiatan ekstra kulikuler (Fitriati, 2012). Di kampus IPB, UI dan beberapa kampus lainnya juga telah menerapkan program bisnis incubator sebagai salah satu program yang difasilitasi oleh pihak kampus untuk mewujudkan kemampuan berwirausaha mahasiswanya. Di ITB, Ciputra dan beberapa kampus lainnya juga diadakan mata kuliah technopreneurship. Akan tetapi, secanggih apapun program kewirausahaan dibentuk, akan tidak ada artinya jika mahasiswa hanya menganggap mempelajari serta mengikuti kegiatan kewirausahaan hanyalah sebagai mata pelajaran akademik saja (Gibb, 2002; Laukkanen, 1998) dan tidak didukung dengan tumbuhnya orientasi berwirausaha dan minat berwirausaha seseorang.

Pendidikan kewirausahaan yang dijalankan baik melalui kurikulum dan program-program kewirausahaan diharapkan dapat menumbuhkan orientasi kewirausahaan seseorang. Orientasi kewirusahaan dapat diukur melalui kemampuan berinovasi dan berkreatifitas, sikap proaktif terhadap peluang usaha, agresif dalam berkompetisi, kemampuan mengambil risiko dan mandiri untuk memulai bisnis baru (Miller, 1983). Sulistyorini (2013) mengemukakan bahwa mahasiswa pada umumnya belum berani mengambil risiko terutama dalam hal penggunaan dana. Pada dasarnya yang memiliki kemampuan dalam hal financial lebih memilih untuk membelanjakan uangnya dalam hal yang konsumtif. Sedangkan mereka tidak berani untuk membelanjakan uangnya pada kegiatan yang mengandung risiko atau aktifitas entrepreneurial.

Universitas Ibn Khaldun (UIKA) merupakan salah satu universitas tertua di Bogor yang juga memiliki visi untuk menjadikan mahasiswanya memiliki kemampuan untuk berwirausaha. Beberapa program dan kegiatan dibuat untuk memfasilitasi mahasiswa agar minat berwirausaha dapat muncul dalam diri setiap mahasiswa. Dengan demikian, berdasarkan latar belakang yang telah diungkapkan diatas, maka penelitian ini bertujuan untuk mengkaji pengaruh pendidikan kewirausahaan dan orientasi kewirausahaan terhadap minat berwirausaha mahasiswa UIKA dengan menjadikan orientasi kewirausahaan sebagai variable mediasi.

\section{B. Metode Penelitian}

Metode analisis data yang digunakan dalam penelitian ini adalah model persamaan struktural atau Structural Equation Modelling (SEM). Penggunaan analisis SEM dalam menganalisis model penelitian diharapkan dapat mengidentifikasikan dimensi-dimensi sebuah construct dan pada saat yang sama akan mengukur pengaruh atau derajat hubungan antara faktor yang telah diidentifikasikan dimensi-dimensinya (Ferdinand, 2006). Keunggulan penggunaan SEM lainnya adalah kemampuannya untuk mengkonfirmasikan dimensi-dimensi dari sebuah konsep atau faktor serta kemampuannya untuk mengukur pengaruh hubungan-hubungan secara teoritis. 
Populasi penelitian adalah seluruh mahasiswa jurusan bisnis dan manajemen di seluruh kampus yang ada di Indonesia. Sample dalam penelitian ini akan ditentukan dengan menggunakan perhitungan sample minimum. Penentuan jumlah sampel minimum untuk SEM menurut (Hair dalam Ferdinand, 2006) adalah tergantung pada jumlah indikator yang ada dan dikalikan lima sampai sepuluh. Jumlah sampel minimum untuk penelitian ini adalah:
Sampel minimum $=19 \times 5=70$ responden (namun dalam penelitian ini jumlah sample yang ditetapkan adalah 120 responden dengan penyebaran kuesioner hingga 150 kuesioner untuk mendapatkan hasil yang lebih akurat dan dapat mewakili populasi).

Definisi operasional merupakan penjabaran akan definisi variabel dan indikator pada penelitian ini. selanjutnya definisi operasional menggambarkan pula pengukuran atas variabel dan indikator yang dikembangkan pada penelitian ini.

Tabel 2: Definisi Operasional Variabel dan Indikator

\begin{tabular}{|c|c|c|c|}
\hline Variabel & $\begin{array}{l}\text { Definisi } \\
\text { Variabel }\end{array}$ & Indikator Variabel & $\begin{array}{l}\text { Definisi Operasional Indikator } \\
\text { Variabel }\end{array}$ \\
\hline \multirow[t]{6}{*}{$\begin{array}{l}\text { Entrepreneurial } \\
\text { Education (X) }\end{array}$} & \multirow{6}{*}{$\begin{array}{l}\text { Proses pemindahan } \\
\text { pengetahuan dari dari teori } \\
\text { ke praktik baik melalui } \\
\text { kurikulum kewirausahaan } \\
\text { maupun program- } \\
\text { program/kegiatan } \\
\text { kewirausahaan. }\end{array}$} & $\begin{array}{l}\text { Xl (materi } \\
\text { kewirausahaan) }\end{array}$ & \multirow{6}{*}{$\begin{array}{l}\text { Keenam indikator ini diukur } \\
\text { melalui beberapa pernyataan } \\
\text { yang dialamatkan pada } \\
\text { mahasiswa tentang ada atau } \\
\text { tidaknya dampak dari beberapa } \\
\text { kurikulum dan program } \\
\text { kewirausahaan } \\
\text { kemampuan mereka untuk } \\
\text { berwirausaha }\end{array}$} \\
\hline & & X2 (motivasi) & \\
\hline & & $\begin{array}{l}\text { X3 (kemampuan/ } \\
\text { keahlian } \\
\text { berwirausah) }\end{array}$ & \\
\hline & & X4 (pendekatan) & \\
\hline & & X5 (fasilitator) & \\
\hline & & $\begin{array}{l}\text { X6 } \\
\text { (program/kegiatan } \\
\text { wirausaha) }\end{array}$ & \\
\hline \multirow{5}{*}{$\begin{array}{l}\text { Entrepreneurial } \\
\text { Orientation }(\mathrm{Y})\end{array}$} & \multirow{5}{*}{$\begin{array}{l}\text { Proses, praktek, dan } \\
\text { kegiatan pengambilan } \\
\text { keputusan yang menuju } \\
\text { pada aktivtas inovasi. }\end{array}$} & Yl (autonomy) & \multirow{5}{*}{$\begin{array}{l}\text { Kelima indikator ini diukur } \\
\text { dengan melihat kemampuan } \\
\text { mahasiswa dalam kemandirian, } \\
\text { berinovasi, bersikap proaktif, } \\
\text { keberanian dalam mengambil } \\
\text { risiko, dan sikap agresif dalam } \\
\text { bersaing }\end{array}$} \\
\hline & & Y2 (innovativeness) & \\
\hline & & Y3 (proactiveness) & \\
\hline & & Y4 (risk taking) & \\
\hline & & $\begin{array}{l}\text { Y5 (competitive } \\
\text { aggressiveness) }\end{array}$ & \\
\hline \multirow{3}{*}{$\begin{array}{l}\text { Entrepreneurial } \\
\text { Intention }(Z)\end{array}$} & \multirow{3}{*}{$\begin{array}{l}\text { Langkah awal suatu proses } \\
\text { pendirian sebuah usaha } \\
\text { yang umumnya bersifat } \\
\text { jangka panjang. }\end{array}$} & Zl (Sikap) & \multirow{3}{*}{$\begin{array}{l}\text { Sikap seseorang terhadap suatu } \\
\text { perilaku dan norma subjektif juga } \\
\text { turut mempertimbangkan faktor- } \\
\text { faktor motivasi yang dapat } \\
\text { mempengaruhi perilaku. } \\
\text { Sebaliknya, faktor ketiga } \\
\text { (perceived behavioral control) } \\
\text { diasumsikan menggambarkan } \\
\text { faktor-faktor non-motivasi yang }\end{array}$} \\
\hline & & Z2 (Norma Subjektif) & \\
\hline & & $\begin{array}{l}\text { Z3 (Perceived } \\
\text { Behavioral Control) }\end{array}$ & \\
\hline
\end{tabular}




\begin{tabular}{|l|l|l|}
\hline & & $\begin{array}{l}\text { dapat mempengaruhi perilaku } \\
\text { (seperti misalnya jika dalam } \\
\text { kasus berwirausaha adalah dari } \\
\text { aspek modal, skill [kemampuan], } \\
\text { tenaga kerja lokasi dan } \\
\text { sebagainya). }\end{array}$ \\
\hline
\end{tabular}

Dalam membuat permodelan SEM perlu dilakukan langkah-langkah berikut ini:

1. Pengembangan model teoritis Langkah pertama yang harus dilakukan dalam mengembangkan model SEM adalah mengembangkan sebuah model penelitian dengan dukungan teori yang kuat melalui berbagai telaah pustaka dari sumber-sumber ilmiah yang berhubungan dengan model yang dikembangkan.

2. Pengembangan diagram alur (path diagram) untuk menunjukkan hubungan kausalitas (sebab akibat). Model penelitian yang telah dibangun pada tahap pertama akan digambarkan pada sebuah path diagram yang akan mempermudah untuk melihat hubungan-hubungan kausalitas yang akan diuji. Konstruk-konstruk dalam path diagram dapat dibedakan menjadi dua kelompok, yaitu:

a. Konstruk Eksogen (exogenous construct), dikenal dengan source variable atau independent variable yang tidak diprediksi oleh variabelvariabel yang lain yang terdapat dalam model.

b. Konstruk Endogen (endogenous construct) yang merupakan faktorfaktor yang diprediksi oleh satu atau beberapa konstruk. Konstruk endogen dapat memprediksi satu atau beberapa kosntruk endogen lainnya, tetapi konstruk endogen hanya dapat berhubungan kausal dengan konstruk endogen.

Sehingga, path diagram yang dikembangkan untuk penelitian ini adalah sebagai berikut: 


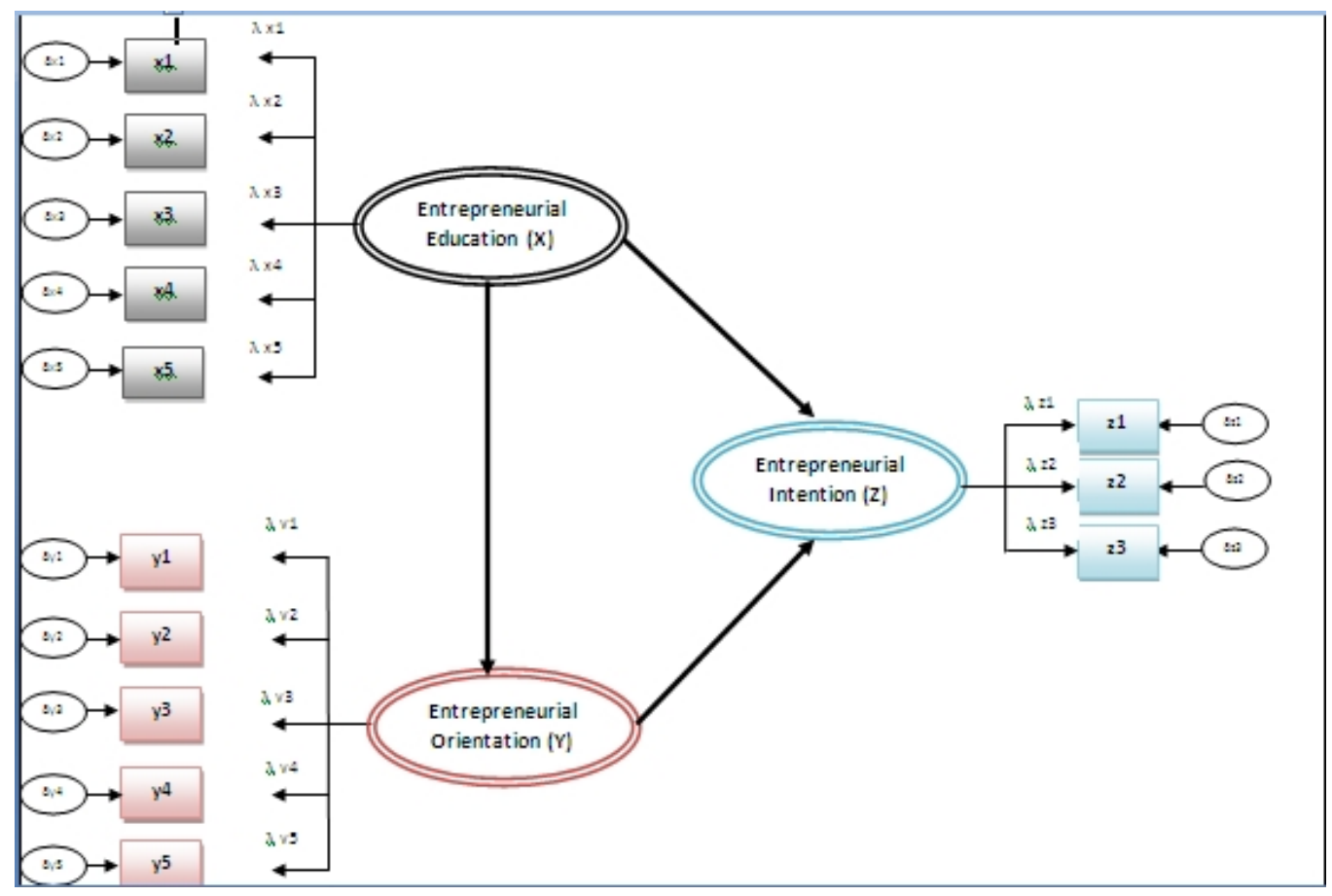

Gambar 2: Model pengukuran lengkap (path diagram)

3. Konversi diagram alur ke dalam serangkaian persamaan strukturan dan spesifikasi model pengukuran.

4. Pemilihan matrik input dan teknik estimasi

SEM menggunakan input data yang hanya menggunakan matriks/kovarian atau matrik korelasi untuk keseluruhan estimasi yang dilakukan. Matrik kovarian digunakan karena memiliki keunggulan dalam menyajikan perbandingan yang valid antara populasi yang berbeda atau sampel yang berbeda dan tidak dapat disajikan oleh korelasi. (Hair et al., dalam Ferdinand, 2006) menganjurkan bahwa jumlah sampel yang sesuai adalah berkisar antara 100 sampai dengan 200 responden, sedangkan ukuran sampel minimum adalah sebanyak 5 responden per estimasi parameter.

5. Menilai problem identifikasi

Problem identifikasi pada dasarnya merupakan problem mengenai ketidakmampuan dari model yang dikembangkan untuk menghasilkan estimasi yang unit. Salah satu solusi untuk problem identifikasi ini adalah dengan memberikan lebih banyak konstrain pada model yang dianalisis dan ini berarti mengeliminasi jumlah estimated coefficient. Oleh karena itu sangat disarankan bila setiap kali estimasi dilakukan muncul problem identifikasi, maka sebaiknya model dipertimbangkan ulang antara lain dengan mengembangkan lebih banyak model konstruk. 
6. Evaluasi kriteria goodness of fit

Pada tahap ini dilakukan pengujian terhadap berbagai kriteria goodness of fit, setelah dipastikan bahwa data yang digunakan sudah memenuhi asumsiasumsi SEM.

\section{Hasil dan Pembahasan}

1. Karakteristik Umum Responden

Berdasarkan jumlah responden yang berhasil dihimpun oleh peneliti adalah berjumlah 152 orang responden, namun responden yang sesuai dengan criteria pada penetapan sample dalam penelitian ini adalah hanya berjumlah 120 orang responden. Responden yang diambil merupakan mahasiswa/i aktif Universitas Ibn Khaldun Bogor yang telah mendapatkan mata kuliah kewirausahaan (dalam kasus ini difokuskan pada mahasiswa program studi Ekonomi Syariah Fakultas Agama Islam). Karakteristik umum responden yang dianalisis meliputi jenis kelamin, dan semester. Berdasarkan informasi yang dikumpulkan oleh peneliti berikut disajikan deskripsi data responden.

Tabel 3: Demografi Responden

\begin{tabular}{|l|l|}
\hline \multicolumn{2}{|c|}{ Jenis Kelamin } \\
\hline Pria & $45 \%$ \\
\hline Wanita & $55 \%$ \\
\hline \multicolumn{2}{|c|}{ Semester } \\
\hline 7 & $30 \%$ \\
\hline 5 & $37 \%$ \\
\hline 3 & $33 \%$ \\
\hline
\end{tabular}

Tabel 3 di atas menjelaskan bahwa berdasarkan jenis kelamin, mayoritas responden pada penelitian ini adalah wanita yaitu 55\%, sedangkan laki-laki adalah sebanyak 45\%. Berdasarkan kriteria penetapan sample yang telah ditetapkan, dimana sample pada penelitian ini adalah mahasiswa yang telah mengambil mata kuliah kewirausahaan pada prodi Ekonomi Syariah Fakutlas Agama Islam Universitas Ibn Khaldun. Maka, responden yang diambil adalah mahasiswa pada semester pembelajaran yang juga bertepatan dengan periode penelitian yaitu mahasiswa pada semester 7, 5, dan 3. Peneliti juga mencoba untuk menyeimbangan proporsi jumlah responden untuk masing-masing semester sehingga diperoleh peserta terbanyak adalah dari semester 5 yaitu 37\%, 33\% dari semester 3, dan 30\% lainnya dari semester 7.

\section{Perilaku Berwirausaha Responden}

Pada sub bab berikut ini diurai dan dianalisis hasil perilaku berwirausaha mahasiswa program studi Ekonomi Syariah Universitas Ibn Khaldun Bogor (UIKA). Berdasarkan informasi yang dikumpulkan oleh peneliti berikut disajikan perilaku berwirausaha responden.

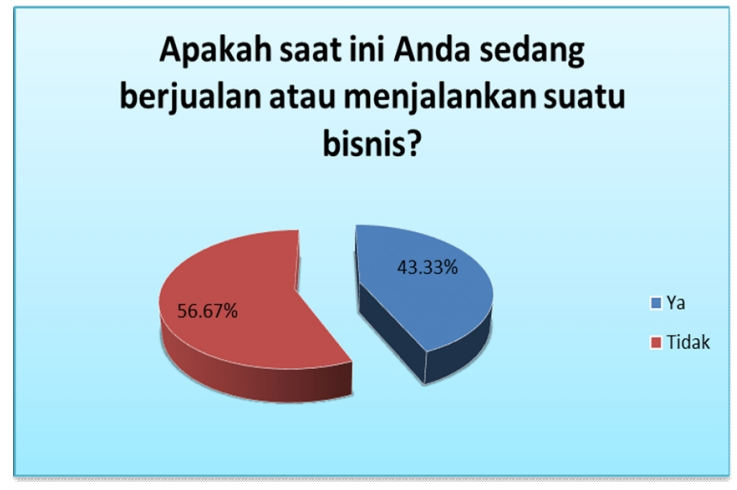

Gambar 3: Prosentase Mahasiswa yang Menjalankan Bisnis 
Gambar 3 menunjukkan bahwa terdapat 43,33\% mahasiswa Ekonomi Syariah UIKA saat ini sedang menjalankan suatu bisnis (sedang berjualan). Berdasarkan hasil pengamatan peneliti, mahasiswa memiliki ketertarikan yang cukup beragam dalam menjual barang dagangannya. Diantaranya ada yang berjualan pulsa, fashion wanita (baju, kosmetik, parfum), menjadi agen asuransi syariah, dan hingga menjadi agen property. Produk yang ditawarkan juga tidak sedikit yang diproduksi sendiri dan atau telah memiliki brand sendiri. Selain itu, peneliti juga melakukan survey terhadap mahasiswa terkait tentang tema skripsi yang nantinya akan diangkat dimana hampir $80 \%$ mahasiswa memilih tema bisnis dan marketing. Hal ini menunjukkan bahwa hampir setengah mahasiswa UIKA sudah memiliki ketertarikan untuk menjadi seorang wirausaha. Sedangkan 56,67 lainnya belum menjalankan bisnis.

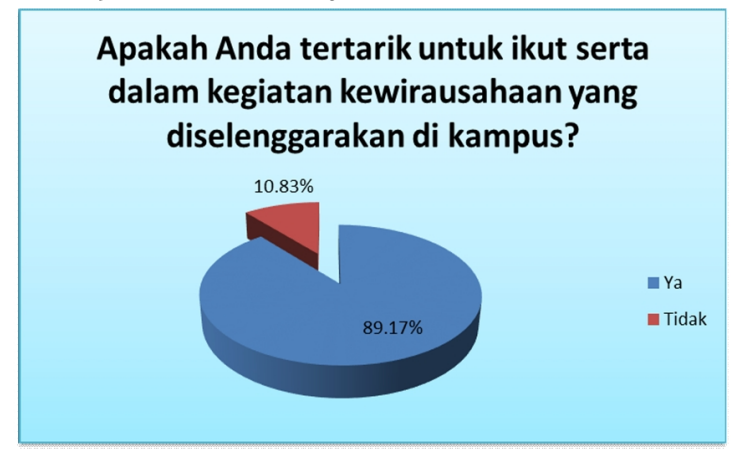

Gambar 4: Prosentase Ketertarikan Mahasiswa untuk Ikut Serta dalam Kegiatan Kewirausahaan kampus mengadakan kegiatan kewirausahaan, baik dalam bentuk seminar, workshop, bazaar dan semacamnya, maka 89,17\% mahasiswa tertarik untuk ikut serta. Hal ini merupakan kabar gembira bagi UIKA dimana perlu memfasilitasi minat mahasiswa dalam berwirausaha melalui kegiatan-kegiatan kewirausahaan. Hanya $10,83 \%$ mahasiswa yang tidak tertarik untuk mengikut. UIKA khususnya pihak fakultas perlu mengakomodir kebutuhan mahasiswa dalam pengembangan keterampilan kewirausahaan. Bentuk dukungan fakultas dapat berupa mendatangkan pembicara pengusaha sukses, pelatihan akuntansi keuangan untuk UMKM, workshop keterampilan tangan (seperti menjahit, merajut, quilting, hingga membuat kue). Dalam jangka panjang, bentuk dukungan fakultas atau bahkan universitas dapat berupa membentuk bisnis incubator kampus, sebagaimana yang telah ada di kampuskampus besar lainnya seperti IPB dan UI.

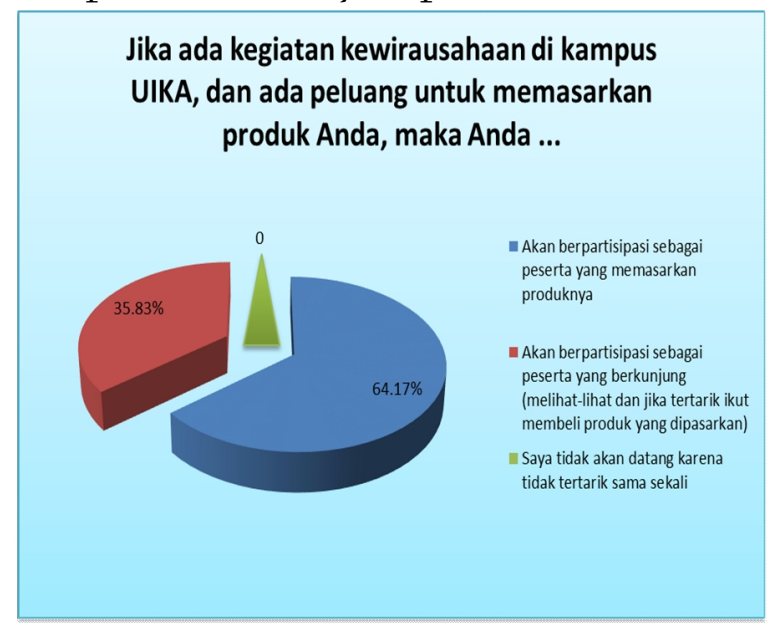

Gambar 5: Prosentase Ketertarikan Mahasiswa untuk Menangkap Peluang dalam Memasarkan Produk 
Semakin mendukung hasil deskriptif sebelumnya, dimana gambar 5 menunjukkan bahwa 64,17 mahasiswa akan berpartisipasi sebagai peserta dalam memasarkan produk mereka jika kampus menyelenggarakan kegiatan kewirausahaan dan memberikan peluang kepada mahasiswa untuk memasarkan produk. Hal ini semakin menguatkan hasil sebelumnya dimana 89,17\% mahasiswa akan berpartisipasi aktif dan ikut serta. Sedangkan sisanya 35,83\% yang juga tertarik untuk berpartisipasi namun hanya sebagai pengunjung, dan akan membeli jika tertarik. Terdapat $0 \%$ atau tidak ada satupun siswa yang sama sekali tidak tertarik dengan kegiatan ini.

\section{Korelasi Antar Variabel Demografi} (Gender \&e Semester) dan Variabel Minat Berwirausaha

Social Feminist Theory (teori feminism social) menyebutkan bahwa selalu ada perbedaan antara pria dan wanita akan sesuatu kecenderungan, keinginan, dan minat. Ordaz, et al (2016); Gonzalez (2017) menjelaskan bahwa jenis kelamin seseorang akan sangat menentukan apakah seseorang minat atau tidak dalam berwirausaha. Oleh sebab itu, pada penelitian ini juga dicoba untuk mengkaji hubungan antara variable demografi gender (jenis kelamin) dan semester terhadap minat untuk berwirausaha yang diukur melalui dimensi sikap berwirausaha (keinginan untuk mengejar karir sebagai wirausahawan), norma subjektif (dukungan dari orang sekitar), dan perceived behavioral control (keyakinan untuk memulai usaha sendiri).

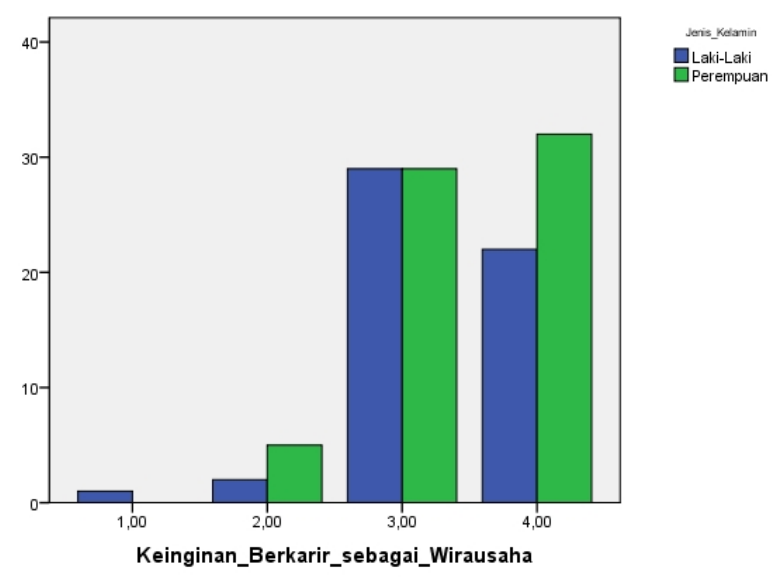

\section{Gambar 6: Korelasi Antara Jenis Kelamin dan Keinginan untuk Berkarir sebagai Wirausaha}

Gambar 6 di atas menunjukkan tabulasi silang antara jenis kelamin dan keinginan mahasiswa untuk berkarir menjadi wirausaha. Tabulasi silang di atas menjelaskan bahwa perempuan lebih banyak memiliki keinginan untuk berwirausaha dibandingkan dengan lakilaki. Hal ini bisa saja erat kaitannya dengan kodrat wanita yang seharusnya lebih banyak tinggal dirumah ketika sudah berkeluarga, sehingga memutuskan untuk berbisnis lebih cocok sebagai karir bagi seorang wanita dibandingkan harus kerja dikantoran. Selain itu, berkembangnya industry fashion disertai dengan adanya kemudahan teknologi dalam menjual produk, turut menyumbang wanita untuk berbisnis. Namun demikian, angka korelasi chi-square menunjukkan tidak ada korelasi yang signifikan antara jenis kelamin terhadap keinginan berkarir sebagai wirausaha ( $p$-value of chi-square > 0,05 yaitu 
0,397). Artinya, untuk menjadi pengusaha dapat dilakukan oleh siapa saja baik oleh pria maupun wanita.

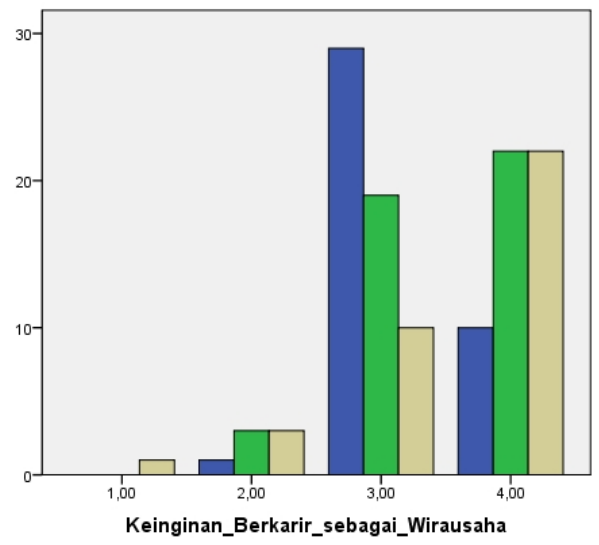

Gambar 7: Korelasi Antara Semester dan Keinginan untuk Berkarir sebagai Wirausaha

Dilihat dari tabulasi silang antara semester dan keinginan mahasiswa untuk berkarir menjadi wirausaha, maka dapat dilihat bahwa mahasiswa semester 5 dan semester 7 lebih dominan untuk berkarir di wirausaha dibandingkan dengan semester 3. Hasil ini dianggap cukup wajar mengingat semester 5 dan 7 lebih banyak mendapatkan pelajaran tentang kewirausahaan dan pengalaman dalam seminar ataupun kegiatan berwirausaha. Selain itu, semester 5 dan 7 merupakan masa-masa dimana mahasiswa mulai didekatkan dan dikenalan dengan dunia kerja, sehingga mereka lebih dulu berpikir untuk masa depan dimana salah satunya berkarir menjadi seorang wirausaha. Hasil penelitian ini juga turut didukung dengan angka korelasi chi-square yang signifikan ( $p$ value of chi-square $<0,05$ yaitu 0,007), yang artinya bahwa ada hubungan antara semester terhadap keinginan berkarir sebagai wirausaha. Melalui tabulasi silang dapat terlihat bahwa semakin tinggi semester yang dijalani maka semakin tinggi pula keinginan untuk berkarir menjadi seorang wirausaha.

Bar Chart

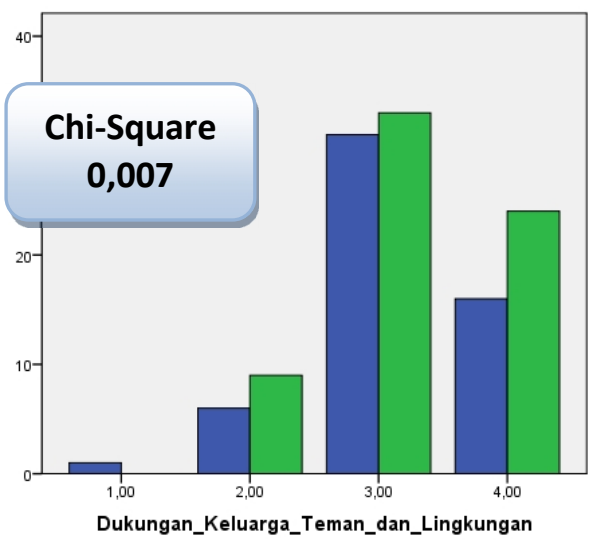

QLaki-Laki Gerempuan

Gambar 8: Korelasi Antara Jenis Kelamin dan Dukungan dari Keluarga, Teman danLingkungan

Tabel 8 menunjukkan bahwa perempuan lebih banyak dalam mendapatkan dukungan dari keluarga, teman dan lingkungan untuk berwirausaha dibandingkan dengan laki-laki. Namun dukungan ini pun terlihat tidak signifikan korelasinya yang digambarkan dengan angka $p$-value pada chi-square >0,05, yaitu 0,555 . Artinya bahwa dukungan yang diberikan oleh keluarga, kerabat, dan teman kepada seseorang untuk berbisnis tidak dibatasi pada apakah dia wanita atau laki-laki. 


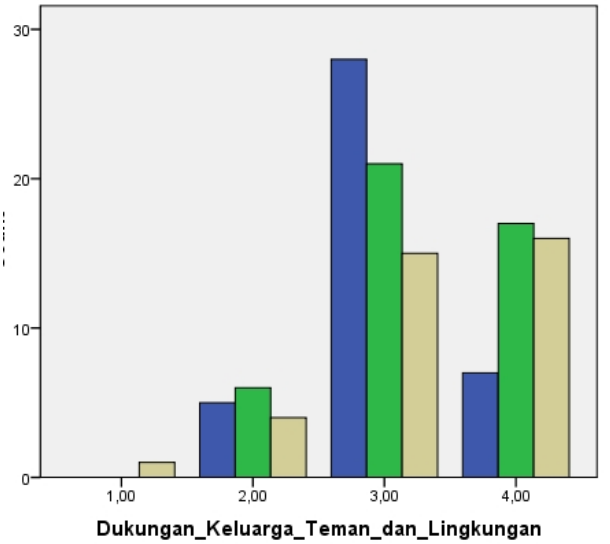

Gambar 9: Korelasi Antara Semester dan Dukungan dari Keluarga, Teman dan Lingkungan

Selain itu, tabel 9 juga menunjukkan bahwa semester 5 dan 7 lebih banyak dalam mendapatkan dukungan dari keluarga, teman dan lingkungan untuk berwirausaha pada skala 4, sedangkan semester 3 lebih dominan dalam mendapatkan dukungan dari keluarga, teman dan lingkungan untuk berwirausaha pada skala 3. Hasil ini pun didukung dengan korelasi yang tidak signifikan antara kedua variable yang digambarkan dengan angka $p$-value pada chi-square >0,05 yaitu 0,108. Artinya bahwa dukungan yang diberikan oleh keluarga, kerabat, dan teman kepada seseorang untuk berbisnis tidak dibatasi pada apakah mahasiswa tersebut berada pada semester 3,5, atau 7 .

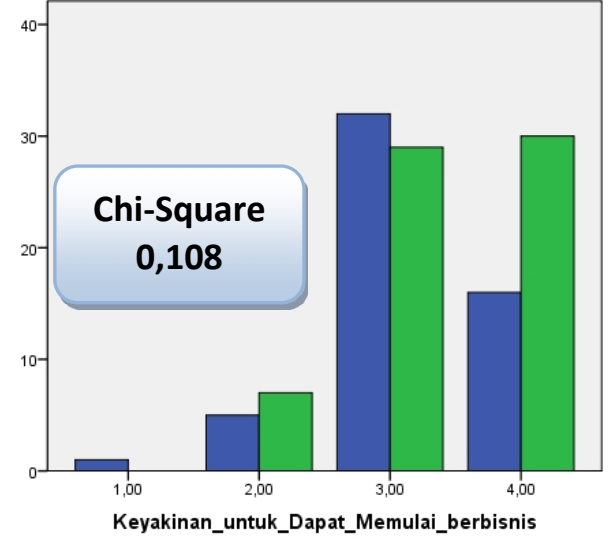

Jeris_kedamin
GLaki-Laki
口Perempuan

Gambar 10: Korelasi Antara Jenis Kelamin dan Keyakinan untuk Dapat Memulai Bisnis

Mayoritas mahasiswa dengan jenis kelamin perempuan merasa sangat yakin bahwa mereka dapat memulai bisnis, sedangkan mayoritas laki-laki merasa yakin bahwa mereka dapat memulai bisnis. Hal ini berarti bahwa perempuan lebih memiliki rasa percaya diri dalam membangun usaha ketimbang laki-laki. Tingginya rasa percara diri perempuan ini pula disebabkan oleh perempuan pada umumnya suka akan tantangan dan mengambil risiko tanpa perlu banyak pertimbangan. Beda halnya dengan lakilaki dimana orientasi mereka adalah menafkahi keluarga sehingga risiko yang memungkinkan untuk terjadi pada dunia bisnis perlu dipertimbangkan dengan matang. Pada dasarnya laki-laki mau untuk berwirausaha dan yakin untuk dapat memulai usaha, namun hanya sebatas yakin saja, dan bukan 'sangat yakin'. Namun demikian angka korelasi antara dua variable ini pun terlihat tidak signifikan ( $p$ value of chi-square > 0,05 yaitu 0,205) yang berarti bahwa baik perempuan maupun 
laki-laki bisa saja memiliki keyakinan yang kuat untuk dapat memulai usaha.

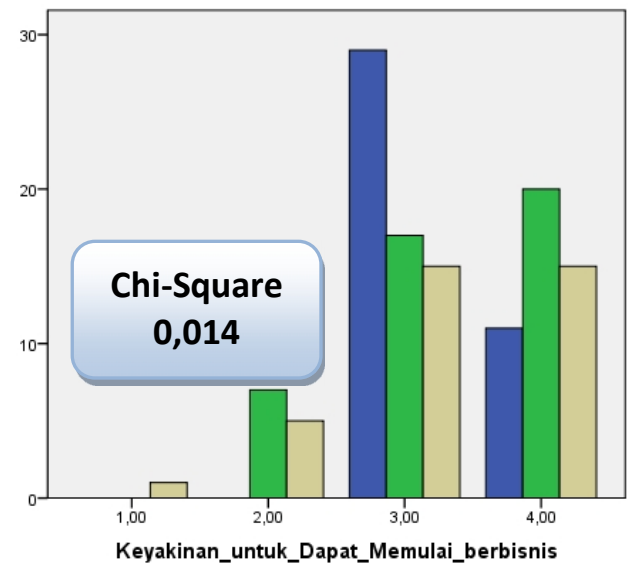

Gambar 11: Korelasi Antara Semester dan Keyakinan untuk Dapat Memulai Bisnis

Mayoritas mahasiswa semester 5 merasa sangat yakin bahwa mereka dapat memulai bisnis, sedangkan mahasiswa semester 3 merasa yakin bahwa mereka dapat memulai bisnis. Menariknya, tidak ada satupun mahasiswa semester 3 yang merasa tidak yakin. Berbeda dengan semester 5 dimana masih terdapat beberapa mahasiswa yang tidak yakin, dan semester 7 dimana terdapat beberapa mahasiswa yang merasa tidak yakin bahwa mereka dapat memulai bisnis. Hal ini menunjukkan bahwa semester 3 cukup optimis bahwa mereka dapat memulai bisnis. Indikasinya adalah bahwa semester 3 belum cukup pengetahuan akan risiko yang kemungkinan dihadapi dalam berwirausaha, sebaliknya semester 5 dan 7 sudah mulai mempertimbangkan risikorisiko yang kemungkinan terjadi, atau bahkan sudah menemukan minat yang sebenarnya apakah akan berwirausaha atau berkarir di kantor. Hasil korelasi juga menunjukkan bahwa hubungan tingkat semester dengan keyakinan untuk dapat memulai bisnis adalah signifikan ( $p$-value of chi-square $<0,05$ yaitu 0,014). Artinya keyakinan untuk memulai usaha sangat berhubungan dengan tingkat pengetahuan dan pembelajaran dalam berwirausaha.

\section{Analisis Model Pengukuran}

Model pengukuran disajikan dengan melihat pada angkat $\mathrm{t}$-value dan standardized loading factor pada setiap indicator dari setiap variabel penelitian. Mengingat pendekatan yang dilakukan dalam penelitian ini adalah two step approach maka diperlukan analisis model pengukuran terlebih dahulu untuk melihat validitas dan reliabilitas dari setiap indicator yang digunakan dalam variabel laten. Menurut Wijanto (2008) validitas indicator diukur dengan mengetahui nilai $t$ value dimana disyaratkan harus di atas ( $\geq$ 1,96), selain itu validitas juga dapat dilihat melalui angka standardized loading factor dimana disyaratkan harus $\geq 0,3$. Berikut disajikan hasil analisis setiap indiakator yang digunakan pada masing-masing variabel laten:

\section{a. Variabel Laten Pendidikan Kewirausahaan \\ Variabel laten pendidikan} kewirausahaan memiliki 6 indikator yaitu diantaranya adalah materi kewirausahaan, motivasi, kemampuan/keahlian berwirausaha, pendekatan pendidikan kewirausahaan, fasilitator/tenaga pengajar kewirausahaan, dan program/kegiatan wirausaha. Selanjutnya, model pengukuran 
dari variabel laten pendidikan kewirausahaan akan diuji validitas dan reliabilitasnya.

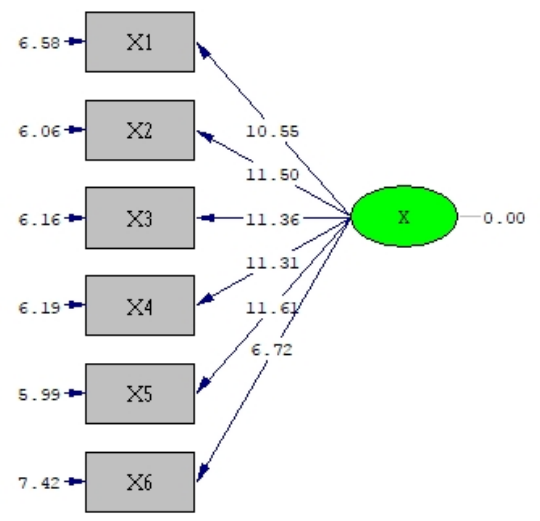

Chi-Square $=12.42, \mathrm{df}=9, \mathrm{P}$-value $=0.19042, \mathrm{RMSEA}=0.057$

\section{Gambar 12: t-value Model Pengukuran} Variabel Pendidikan Kewirausahaan

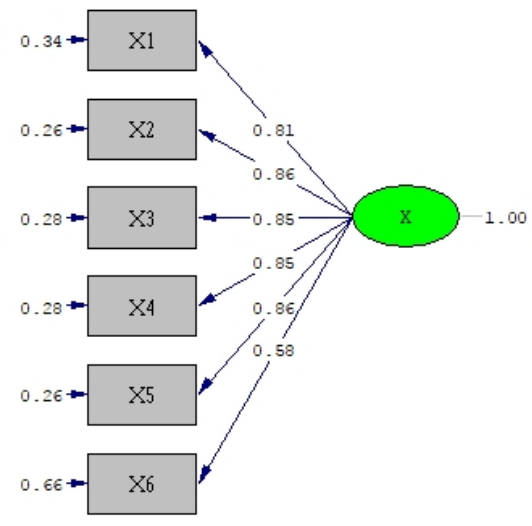

Chi-Square $=12.42, \mathrm{df}=9, \mathrm{P}$-value $=0.19042, \mathrm{RMSEA}=0.057$

\section{Gambar 13: SLF Model Pengukuran Variabel Pendidikan Kewirausahaan}

Gambar diatas menunjukkan bahwa nilai RMSEA-nya adalah $0,057 \leq$ 0,08 yang menunjukkan bahwa kecocokan keseluruhan model (overall model fit) atau kecocokan data dengan model adalah close fit. T-value untuk seluruh indicator sudah memenuhi syarat asumsi yaitu $\geq 1,96$ dan faktor standar (standardized loading factor/SLF) dari item pernyataan adalah valid atau memenuhi syarat karena nilai SLF-nya $\geq 0,30$ (Wijanto, 2008). Model pengukuran pendidikan kewirausahaan memiliki reliabilitas yang baik ( $C R \geq 0,95$ dan VE 20,65$)$. Dengan demikian dapat disimpulkan secara umum bahwa kecocokan keseluruhan model untuk model pengukuran variabel pendidikan kewirausahaan adalah baik, demikian juga validitas dan reliabilitasnya.

\section{b. Variabel Laten Orientasi \\ Kewirausahaan}

Variabel laten orientasi kewirausahaan memiliki 5 indikator yaitu diantaranya adalah autonomy, innovativeness, proactiveness, risk taking, dan competitive agresiveness. Selanjutnya, model pengukuran dari variabel laten orientasi kewirausahaan akan diuji validitas dan reliabilitasnya.

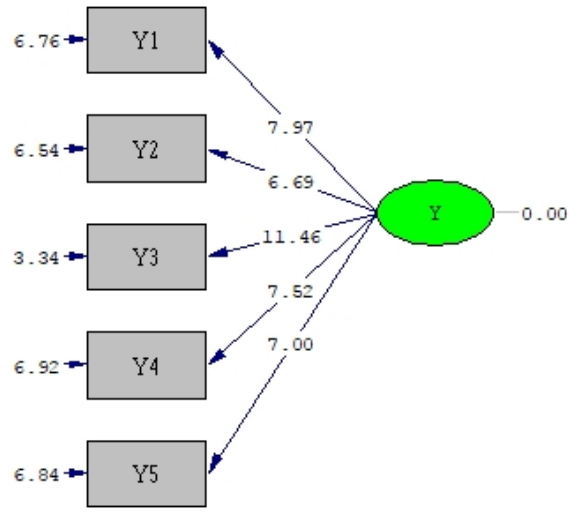

Chi-Square=6.99, df=4, P-value=0.13641, RMSEA $=0.079$

Gambar 14: t-value Model Pengukuran Variabel Orientasi Kewirausahaan 


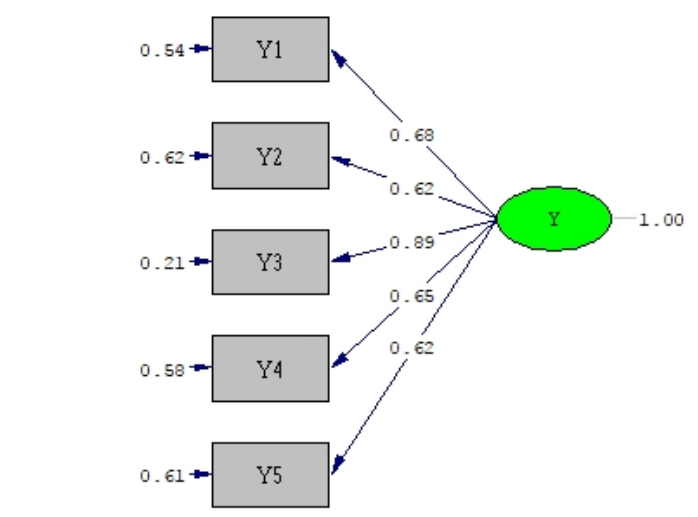

Chi-Square $=6.99, \mathrm{df}=4, \mathrm{P}-\mathrm{value}=0.13641, \mathrm{RMSEA}=0.079$

\section{Gambar 15: SLF Model Pengukuran}

Variabel Orientasi Kewirausahaan

Gambar diatas menunjukkan bahwa nilai RMSEA-nya adalah 0,079 $\leq$ 0,08 yang menunjukkan bahwa kecocokan keseluruhan model (overall model fit) atau kecocokan data dengan model adalah close fit. T-value untuk seluruh indicator sudah memenuhi syarat asumsi yaitu $\geq 1,96$ dan faktor standar (standardized loading factor/SLF) dari item pernyataan adalah valid atau memenuhi syarat karena nilai SLF-nya $\geq 0,30$ (Wijanto, 2008). Model pengukuran orientasi kewirausahaan memiliki reliabilitas yang baik ( $C R \geq 0,82$ dan VE $\geq 0,50)$. Dengan demikian dapat disimpulkan secara umum bahwa kecocokan keseluruhan model untuk model pengukuran variabel orientasi kewirausahaan adalah baik, demikian juga validitas dan reliabilitasnya.

\section{c. Variabel Laten Minat Wirausaha}

Variabel laten minat wirausaha memiliki 3 indikator yaitu diantaranya adalah sikap, norma subjektif, dan perceived behavioral control. Selanjutnya, model pengukuran dari variabel laten minat kewirausahaan akan diuji validitas dan reliabilitasnya.

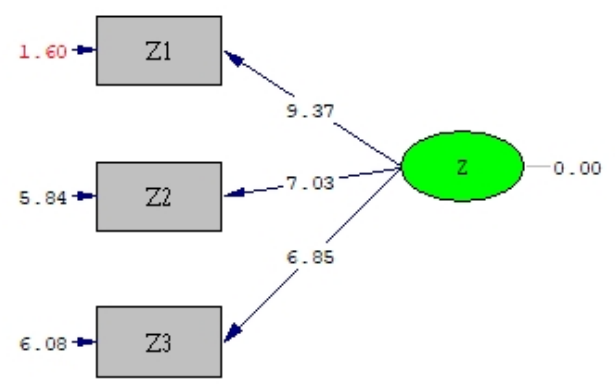

Chi-Square $=0.00, d f=0, P-$ value $=1.00000$, RMSEA $=0.000$

Gambar 16: t-value Model Pengukuran Variabel Minat Wirausaha

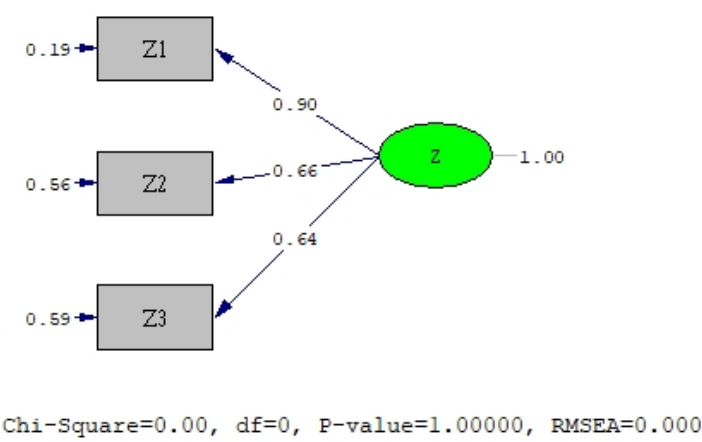

Gambar 17: SLF Model Pengukuran Variabel Minat Wirausaha

Gambar diatas menunjukkan bahwa nilai RMSEA-nya adalah $0,000 \leq$ 0,08 yang menunjukkan bahwa kecocokan keseluruhan model (overall model fit) atau kecocokan data dengan model adalah close fit. T-value untuk seluruh indicator sudah memenuhi syarat asumsi yaitu $\geq 1,96$ dan faktor standar (standardized loading 
factor/SLF) dari item pernyataan adalah valid atau memenuhi syarat karena nilai SLF-nya $\geq 0,30$ (Wijanto, 2008). Model pengukuran minat berwirausaha memiliki reliabilitas yang baik ( $C R \geq 0,78$ dan VE $\geq$ 0,55 ). Dengan demikian dapat disimpulkan secara umum bahwa kecocokan keseluruhan model untuk model pengukuran variabel minat wirausaha adalah baik, demikian juga validitas dan reliabilitasnya.

\section{Uji Kecocokan Model Struktural}

Analisis SEM menggunakan "two step approach", oleh karena itu setelah langkah pertama menghasilkan model pengukuran dari model penelitian yang valid dan reliable, maka dilakukan langkah kedua yaitu analisis model struktural.
Dalam uji hipotesis, sebuah hipotesis penelitian diterima jika angka absolute nilai $t \geq 1,96$ dengan tanda koefisien sesuai dnegan hipotesis penelitian yang diajukan (positif atau negative).

Pada model penelitian ini menunjukkan pengaruh pendidikan kewirausahaan terhadap orientasi kewirausahaan (hipotesis 1), pengaruh orientasi kewirausahaan terhadap minat wirausaha (hipotesis 2), pengaruh pendidikan kewirausahaan terhadap minat wirausaha secara langsung (hipotesis 3), dan pengaruh pendidikan kewirausahaan terhadap minat wirausaha secara tidak langsung (hipotesis 4). Hasil estimasi dari model struktural model penelitian pertama ditunjukkan melalui diagram lintasan berikut ini:

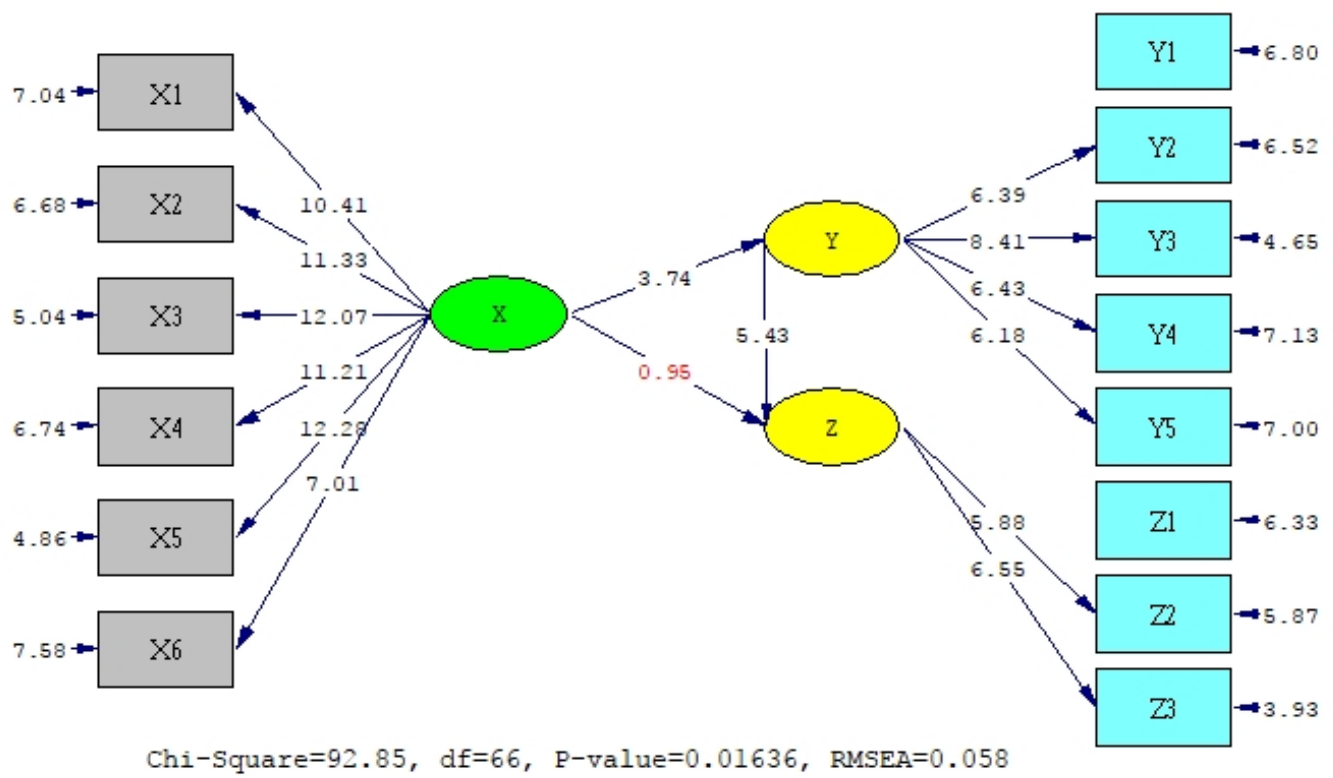

Gambar 18: Diagram Lintasan Hybrid ModelPenelitian (nilai-t) 


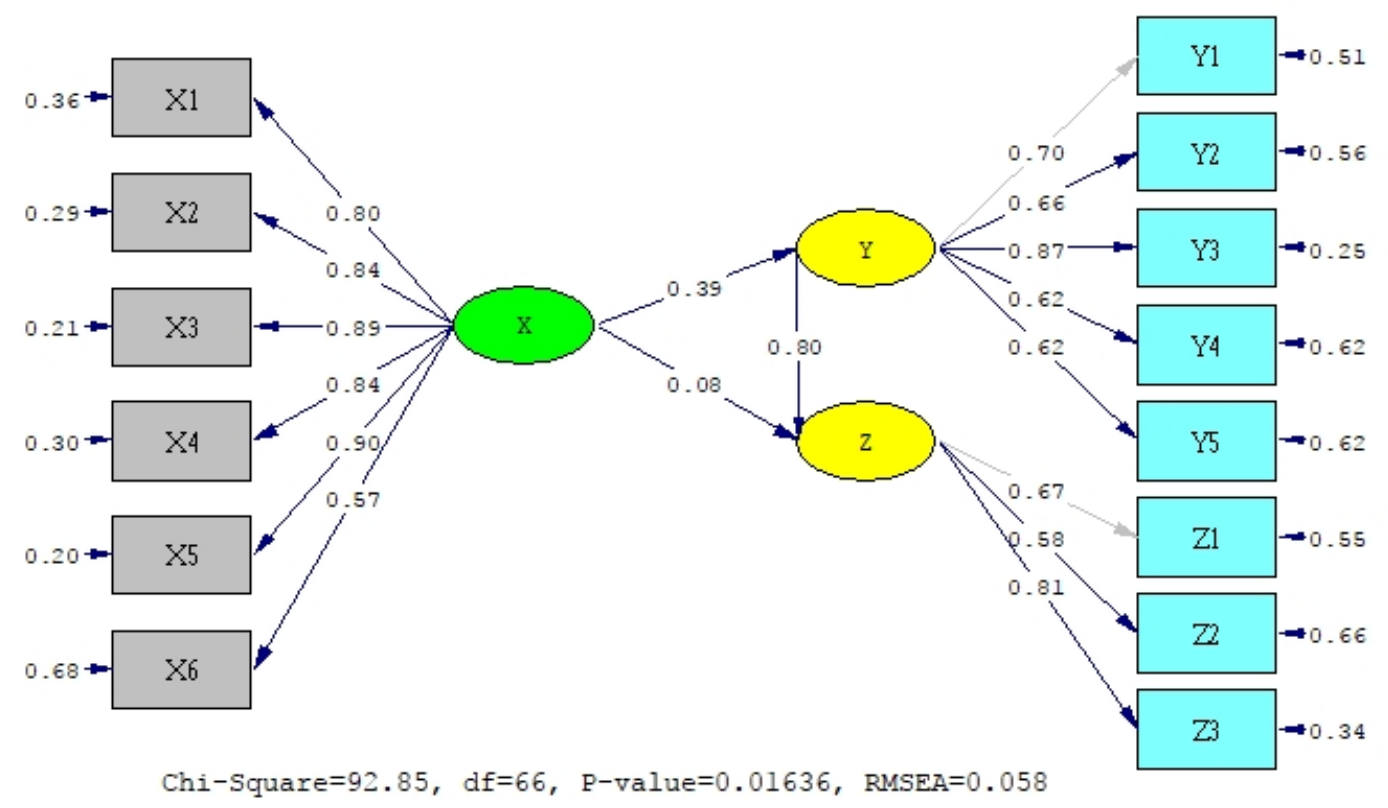

Gambar 19: Diagram Lintasan Hybrid Model Penelitian (Solusi Standar)

Nilai GOFI untuk model struktural dari model penelitian dapat dilihat pada tabel dibawah ini:

Tabel 4: Goodness of Fit Indices (GOFI) Model Struktural

\begin{tabular}{|l|r|l|l|}
\hline \multicolumn{1}{|c|}{ GOFI } & Nilai Hasil Hitung & $\begin{array}{c}\text { Nilai standar untuk } \\
\text { kecocokan model }\end{array}$ & \multicolumn{1}{|c|}{ Kesimpulan } \\
\hline p-value & 0,01636 & -value $\geq 0,05$ & Marginal Fit \\
\hline RMSEA & 0,058 & RMSEA $\leq 0,08$ & Good Fit \\
\hline NFI & 0,99 & NFI $\geq 0,90$ & Good Fit \\
\hline NNFI & 0,99 & NNFI $\geq 0,90$ & Good Fit \\
\hline CFI & 0,99 & CFI $\geq 0,90$ & Good Fit \\
\hline IFI & 0,99 & IFI $\geq 0,90$ & Good Fit \\
\hline $\begin{array}{l}\text { Standardized } \\
\text { RMR }\end{array}$ & 0.00 & $\begin{array}{l}\text { Standardized RMR } \\
\leq 0,05\end{array}$ & \\
\hline GFI & 0,99 & GFI $\geq 0,90$ & Good Fit \\
\hline
\end{tabular}

Berdasarkan tabel diatas dapat demikian dapat disimpulkan bahwa model terlihat bahwa untuk model struktural, structural pada penelitian ini adalah baik nilai standardized RMR, p-value, sehingga dapat dilakukan analisis standardized RMR, GFI RMSEA, NFI, berikutnya yaitu analisis hipotesis. NNFI, CFI, dan IFI menunjukkan nilai GOFI adalah baik (good fit). Dengan 
Pengujian koefisien determinasi minat wirausaha adalah sebesar 70\%, pada penelitian ini dapat dilihat pada persamaan berikut ini:

$\mathrm{Y}=0,38^{*} \mathrm{X}$, Errorvar. $=0,85, \mathrm{R}^{2}=0,15$

$Z=0,80 * Y+0,083^{*} X$, Errorvar. $=0.30, R^{2}=$ 0,70

Berdasarkan persamaan pada model diatas, maka diperoleh kesimpulan bahwa, kemampuan variabel pendidikan kewirausahaan dalam menjelaskan variabel orientasi wirausaha adalah sebesar $15 \%$, sedangkan sisanya $85 \%$ dijelaskan oleh variabel lainnya diluar model penelitian. Sedangkan kemampuan variabel pendidikan kewirausahaan dan orientasi kewirausahaan dalam menjelaskan variable

sedangkan sisanya 30\% dijelaskan oleh variabel lainnya diluar model penelitian. Hasil penelitian ini menunjukkan pentingnya peran pendidikan kewirausahaan dan munculnya orientasi kewirausahaan terhadap minat wirausaha mahasiswa.

\section{Hasil Pengujian Hipotesis}

Adapun ikhtisar hasil analisis hipotesis penelitiian ditunjukkan pada tabel dibawah ini. Berdasarkan tabel tersebut dapat dilihat bahwa dari 2 hipotesis penelitian sebagaimana didefinisikan di bab 3 hanya 1 hipotesis yang signifkan sedangkan 1 lainnya tidak signifikan.

Tabel 5: Hasil Uji Signifikansi Model Struktural Penelitian

\begin{tabular}{|l|l|l|l|l|}
\hline $\begin{array}{l}\text { Hipotesi } \\
\text { s }\end{array}$ & Pernyataan Hipotesis & SLF & t-value & Keterangan \\
\hline $\mathrm{Hl}$ & $\begin{array}{l}\text { Pendidikan } \\
\text { Kewirausahaan } \rightarrow \\
\text { Orientasi Kewirausahaan }\end{array}$ & 0,39 & 3,74 & $\begin{array}{l}\text { Positif- } \\
\text { signifikan, Data } \\
\text { mendukung } \\
\text { model penelitian }\end{array}$ \\
\hline $\mathrm{H} 2$ & $\begin{array}{l}\text { Orientasi Kewirausahaan } \\
\rightarrow \text { Minat Wirausaha }\end{array}$ & 0,80 & 5,43 & $\begin{array}{l}\text { Positif- } \\
\text { signifikan, Data } \\
\text { mendukung } \\
\text { model penelitian }\end{array}$ \\
\hline $\mathrm{H3}$ & $\begin{array}{l}\text { Pendidikan } \\
\text { Kewirausahaan } \rightarrow \text { Minat } \\
\text { Wirausaha }\end{array}$ & 0,08 & 0,95 & $\begin{array}{l}\text { Positif- } \\
\text { signifikan, Data } \\
\text { tidak } \\
\text { mendukung } \\
\text { model penelitian }\end{array}$ \\
\hline $\mathrm{H4}$ & $\begin{array}{l}\text { Pendidikan } \\
\text { Kewirausahaan } \rightarrow \\
\text { Orientasi Wirausaha } \rightarrow \\
\text { Minat Wirausaha }\end{array}$ & 0,31 & 3,39 & $\begin{array}{l}\text { Positif- } \\
\text { signifikan, Data } \\
\text { mendukung } \\
\text { model penelitian }\end{array}$ \\
\hline
\end{tabular}


Tabel 5 menunjukkan hasil hipotesis pengaruh antar variable eksogen terhadap variable endogen baik secara langsung maupun tidak langsung. Pendidikan kewirausahaan berpengaruh positif dan signifikan terhadap orientasi kewirausahaan mahasiswa. Artinya, jika pendidikan kewirausahaan diberikan kepada mahasiswa, ditingkatkan lagi kualitasnya, maka mahasiswa akan memiliki orientasi untuk berwirausaha. Mahasiswa akan semakin terasah dalam hal berinovasi, berpikir kreatif, hingga berani mengambil risiko yang merupakan karakteristik seorang pengusaha. Hasil ini turut mengevaluasi pendidikan kewirausahaan yang telah diberikan oleh universitas (fakultas) kepada mahasiswa dimana pendidikan kewirausahaan yang saat ini sudah dijalankan dianggap efektif dalam membentuk orientasi mahasiswa untuk dapat berwirausaha. Hasil penelitian ini turut didukung dengan penelitian yang dilakukan oleh Mwatsika \& Sankhulani (2016); Baba (2014) yang menyatakan bahwa pendidikan kewirausahaan berkontribusi posiitf dalam meningkatkan pengetahuan wirausaha mahasiswa serta orientasi mahasiswa untuk menjadi seorang wirausaha. Bilic, Prka and Vidovic (2011) menegaskan bahwa pendidikan kewirausahaan akan memicu mahasiswa untuk secara aktif memperoleh informasi tentang kewirausahaan baik melalui workshop, seminar, kegiatan social, hingga sponsor (beasiswa). Aktifiitas ini cenderung akan menjadikan mahasiswa lebih siap dalam memulai wirausaha khususnya pada saat mereka lulus kuliah.

Hasil penelitian ini juga menunjukkan bahwa mahasiswa yang memiliki orientasi kewirausahaan maka akan berdampak positif terhadap minat wirausaha mahasiswa. Artinya, semakin besar orientasi kewirausahaan seseorang, maka akan semakin tinggi pula minat seseorang untuk berwirausaha. Jika universitas memiliki tujuan untuk menghasilkan lulusan yang tidak hanya menjadi pegawai akan tetapi juga menjadi pencipta lapangan kerja, maka sudah seharusnya orientasi kewirausahaan mulai ditumbuhkan sejak semester 1 sekalipun. Hasil penelitian ini juga didukung dengan beberapa penelitian sebelumnya yaitu $\mathrm{Wu}$ (2009); Suharti dan Sirine (2011) menyebutkan bahwa orientasi kewirausahaan secara positif berpengaruh terhadap minat kewirausahaan seseroang. Baba (2014) turut menegaskan bahwa orientasi kewirausahaan terbukti secara positif dapat menumbuhkan minat wirausaha mahasiswa. Namun demikian, perlu dukkungan penuh dari pemerintah (dalam hal ini Menteri Pendidikan) untuk mendesign kurikulum yang comprehensive dan beneficial di universitas-universitas agar dapat mempersiapkan mahasiswa universitas untuk menjadi seorang entrepreneur yang mandiri.

Namun demikian, pendidikan kewirausahaan tidak berpengaruh secara langsung terhadap minat berwirausaha mahasiswa yang ditunjukkan dengan angka t-value < 1,96 yaitu 0.95. Hal ini berarti 
bahwa pendidikan kewirausahaan tidak cukup untuk menumbuhkan minat mahasiswa untuk berwirausaha, atau dengan kata lain, mahasiswa tidak akan serta merta langsung memilki minat untuk berbisnis hanya dengan diberikan perkuliahan tentang entrepreneurship maupun seminar-seminar kewirausahaan yang diselenggarakan oleh kampus. Hal ini sejalan dengan penelitian yang dilakukakn oleh Mwatsika \& Sankhulani (2016) yang menyatakan bahwa pendidikan kewirausahaan dapat membentuk seseorang mahasiswa untuk memiliki minat berwirausaha, meskipun hubungannya adalah lemah. Indarti \& Rostiani (2008); Nastiti, dkk (2010) juga menyatakan bahwa pendidikan kewirausahaan tidak serta merta dapat menumbuhkan minat wirausaha mahasiswa melainkan melalui adanya kesiapan instrument dengan baik serta adanya pengalaman bekerja sebelumnya. Selain itu juga perlu ada dukungan social dari keluarga dan kerabat agar seseorang dapat memiliki minat berwirausaha Mustikawati dan Bachtiar (2008).

Meskipun tidak memiliki pengaruh yang langsung, hasil penelitian juga membuktikan bahwa pendidikan kewirausahaan dapat berpengaruh terhadap minat wirausaha mahasiswa namun secara tidak langsung, yakni melalui orientasi kewirausahaan. Artinya, pendidikan kewirausahaan akan efektif menumbuhkan minat wirausaha jika dengan mendapatkan pendidikan kewirausahaan mahasiswa tumbuh orientasinnya untuk berwirausaha. Maka dengannya orientasi kewirausahaan berperan penting dalam memediasi pengaruh pendidikan kewirausahaan terhadap minat wirausaha. Hal ini juga sejalan dengan penelitian yang dilakukan oleh Baba (2014) dimana orientasi kewirausahaan perlu ditumbuhkan dengan adanya dukungan pemerintah melalui program-program pemerintah.

\section{Kesimpulan}

Berdasarkan hasil analisis pada sub bab sebelumnya, maka berikut kesimpulan yang dapat diberikan dalam penelitian ini yaitu: (i) Entrepreneurial education berpengaruh positif dan signifikan terhadap entrepreneurial orientation mahasiswa UIKA; (ii) Entrepreneurial orientation berpengaruh positif dan signifikan terhadap entrepreneurial intention mahasiswa UIKA; (iii) Entrepreneurial education berpengaruh positif namun tidak signifikan terhadap entrepreneurial intention mahasiswa UIKA secara langsung; (iv) Entrepreneurial education berpengaruh positif dan signifikan terhadap entrepreneurial intention mahasiswa UIKA secara tidak langsung (melalui entrepreneurial orientation); Maka, berikut beberapa rekomendasi yang dapat peneliti berikan kepada manajemen universitas dan fakultas khususnya Fakultas Agama Islam Universitas Ibn Khaldun Bogor: (i) Hendaknya universitas/fakultas meningkatkan pendidikan kewirausahaan melalui program-program dan kegiatan yang dapat menumbuhkan orientasi dan minat mahasiswa UIKA untuk 
berwirausaha; (ii) disamping menciptakan program-program kewirausahaan, diharapkan universitas/fakultas juga mendukung dalam hal sarana dan prasarana (iii) universitas/fakultas dapat bekerja sama dengan beberapa lembaga eksternal dan pemerintahan setempat maupun lembaga keuangan untuk mendukung mahasiswa berwirausaha, seperti misalnya untuk mendukung aspek permodalan universitas/fakultas dapat bekerja sama dengan lembaga-lembaga keuangan baik bank maupun non-bank, untuk mendukung aspek pelatihan kewirausahaan Tazkia dapat bekerja sama dengan perusahaan-perusahaan atau industri-industri rumahan untuk melaksanakan program magang (entrepreneurial internship program) atau yang dewasa ini dikenal dengan program Co-op, mendirikan bisnis incubator kampus dan beberapa program kewirausahaan lainnya. Kerjasama dengan pemerintah dapat dibangun dengan melaksanakan program yang disebut dengan Program Mahasiswa Wirausaha (PMW).

\section{DAFTAR PUSTAKA}

Baba, M. (2014). Relationship Between Entrepreneurial Orientation, Entrepreneurial Education, Self Efficacy, and Entrepreneurial Intention Among Undergraduate Students at Nigerian Universities. Dissertation of Othman Yeop Abdullah Graduate School of Business, University Utara Malaysia.

Bilic, I., Prka, A., \& Vidovic, G. (2011). How Does Education Influence
Entrepreneurship Orientation? Case Study of Crotia. Management, Vol 16, No 1,pp 115-128.

Carree, M.A., \& Thurik, A.R. (2002). The Impact of Entrepreneurship on Economic Growth. Chapter Prepared for International Handbook of Entrepreneurship Research.

Covin, J.G., \& Wales, W.J. (2011). The Measurement of Entrepreneurial Orientation. DOI: $\quad 10.1111 / \mathrm{j} / 1540$ 6520.2010.00432.x: Baylor University

Choo, S., \& Wong, M. (2006). Entrepreneurial Intention: Triggers and Barriers to New Venture Creations in Singapore. Singapore Management Review 28 (2).

Fashoyin, T., \& Tiraboschi, M. (2012). Youth Unemployment and Joblessness: Causes, Consequences, Responses. UK: Cambridge Scholars Publishing.

Fayolle, A. (2007). Handbook of Research in Entrepreneurship Education-A Contextual Perspective. Volume 2. Cheltenham (UK): Edward Elgar.

Fayolle, A., \& Klandt, H. (2006). International Entrepreneurship Education, Issues and Newness. Cheltenham (UK): Edward Elgar.

Ferdinand, A (2006). Structural Equation Modelling dalam Peneltian Manajemen. Edisi 2, Seri Pustaka Kunci 03/BP UNDIP

Fitriati, R. (2012). Entrepreneurship Education: Toward Models in Several Indonesia's University. In Prosiding 
the 4th International Conference on Indonesian Studies: Unity, Diversity and Future (pp. 681-698)

Gibb, A.A. (2002). In Pursuit of A New Entreprise and Entrepreneurship Paradigm For Learning: Creative Deconstruction, New Values, New Ways of Doing Things and New Combinations of Knowledge. International Journal of Entrepreneurial Behavior and Research, 5 (3).

Gurbuz, G., \& Aykol, S (2008). Entrepreneurial Intentions of Young Educated Public in Turkey. Journal of Global Strategic Management, 4(1): 47-56.

Helyer, R. (2011). Aligning Higher Education with the World of Work. Higher Education, Skills and Work Based Learning. Vol.1 No.2 pp,95-105. Emerald Group Publishing Limited.

Honig, B (2004). Entrepreneurship Education: Toward a Model of Contingency-Based Business Planning. Academy of Management Learning and Education, 3(3).

Iskandarini (2011). Kesan Pendidikan Keusahawanan dan Halangan Keusahawanan terhadap Niat Keusahawanan di Kalangan PelajarPelajar Pendidikan Tinggi. Program Pascasarjana Doktor Falsafah. Universiti Utara Malaysia.

Jonsson, C., \& Jonsson, T. (2002). Entrepreneurial Learning: and Informed Way of Learning. The Case of Enterprising and Business Venturing, 18 (2).
Katz, J., \& Gartner, W. (1988). Properties of Emerging Organizations. Academy of Management Review 13 (3).

Krueger, N.F., \& Carsrud, A.L. (1993). Entrepreneurial Intentions: Applying the Theory of Planned Behavior. Entrepreneurship dan Regional Development $5(4)$.

Laukkanen, M. (1998). Exploring Alternative Approaches in High Level Entrepreneurship Education. Paper presented at the Loth Nordic Conference on Small Business Research, Waxjo.

Lee, S.H., \& Wong, P.K (2004). An exploratory study of technopreneurial intentions: A career anchor perspective. Journal of Business Venturing, $19(1)$.

Lumpkin, G.T., \& Des, G.G (1996). Clarifying the Entrepreneurial Orientation Construct and Lingking it to Performance. Academy of Management Review, 21 (1).

Mars, M.M., \& Ginter, M.B. (2012). Academic Innovation and Autonomy; An Exploration of Entrepreneurship Education Within American Community Colleges and The Academic Capitalist Context. Community College Review 2012 40:75.

McStay, D. (2008). An Investigation of Undergraduate Student SelfEmployment Intention and The Impact of Entrepreneurship Education and Previous Entrepreneurial Experience. Submitted in Partial Fulfilment of The Requirements of 
The Degree of Doctor of Philosophy. School of Business Bond University, Australia.

Miller, D. (1983). The Correlates of Entrepreneurship in Three Types of Firms. Management Science Vol 29, No. 7, July 1983. USA

Mwatsika, C., \& Sankhulani, E .(2016). Effect of Entrepreneurship Education on Students Orientation toward Entrepreneurship at the Malawi Polythecnic. International Journal of Business and Economic Research, Vol 5, Issue, 6, pp 235-245.

Nastiti, T., Indarti, N., \& Rostiani, R. (2010). Minat Berwirausaha Mahasiswa Indonesia dan Cina. Manajemen dan Bisnis, Vol. 9 No.2, September, 2010.

Pittaway, L., \& Cope, J. (2012). Entrepreneurship Education: A Systematic Review of The Evidence. International Small Business Journal 2007 25: 479 .

Priyanto, S.H. (2009). Mengembangkan Pendidikan Kewirausahaan di Masyarakat. Adragogia - Jurnal PNFI, Volume 1 No 1.

Rahmawati, P., Suwarto, D. H., \& Endarwati, M. L. (2010). Technopreneruship Course Development Program, Yogyakarta.
Schillb, S. (2011). Entrepreneurial Orientation - What is it and How can it be useful for policy and Program Development? Vol 1, Issue 5-6.

Sulistyorini, U. T. (2013). Metode Pembelajaran Kewirausahaan dalam Membangun Perilaku Kewirausahaan. Jurnal Administrasi Bisnis. Vol. 4, No.l.

Thompson, J.L. (2004). The Facets of The Entrepreneur: Identifying Entrepreneurial Potential, Management Decision, 42(2).

U.S. Department of State/Bureau of International Information Programs. Principles of Entrepreneurship.

Wu, J. (2009). Entrepreneurial Orientation, Entrepreneurial Intent and New Venture Creation: Test of a Framework in a Chinese Context. Dissertation of the Faculty of Virginia Polythecnic Institute and State University, Blacksburg, Virginia.

http://www.bps.go.id/tab sub/view.php?ka $\mathrm{t}=1 \&$ tabel=1\&daftar=1\&id subyek=06\&nota $\mathrm{b}=4$ 